\title{
Pengembangan Media Pembelajaran Matematika Interaktif Berbasis Konstruktivisme Untuk Siswa SMA Kelas X Pada Materi Jarak Pada Bangun Ruang
}

\author{
Lusi Englita ${ }^{1}$ \\ ${ }^{1}$ Akademi Maritim Sapta Samudra, \\ Jl.Gaduang No.17, Sumatera Barat, Indonesia \\ lusienglita@ymail.com
}

\begin{abstract}
Visualization capabilities is a very important skill in mathematics learning. Having a better visualization capabilities students will understand the subject matter well, particularly in geometry material as the material within the geometry. But the fact that the school found that the visualization capabilities of students is still low. One effort to improve visualization upon ability students is to develop media based interactive mathematics constructivism. The purpose of this development is to produce a valid instructional media, practical and effective. This development research uses a Plomp model consisting of three phases namely: preliminary, prototyping, and assessment. Subjects were students of class X SMAN 1 Koto XI Tarusan. The results of validity of media based interactive learning constructivist mathematics have valid criteria in content and construct. Media Learning has met the criteria of practical because it can be done well in learning activities. Media effective learning has met the criteria for being able to increase the activity of student learning and mastery learning outcomes over a predetermined classical completeness. Thus, it can be concluded that the media based interactive learning constructivist mathematics was valid, practical and effective.
\end{abstract}

Keywords: Visualization Capabilities, Media Based Mathematics Constructivism, Plomp Model

\begin{abstract}
Abstrak
Kemampuan visualisasi merupakan keterampilan yang sangat penting dalam pembelajaran matematika. Dengan memiliki kemampuan visualisasi yang lebih baik maka akan membantu siswa memahami materi pelajaran dengan baik, khususnya materi bagun ruang. Namun fakta yang ditemukan di sekolah bahwa kemampuan visualisasi siswanya masih rendah. Salah satu upaya untuk meningkatkan kemampuan visualisasi siswa adalah dengan mengembangkan media pembelajaran matematika interaktif berbasis konstruktivisme pada materi bangun ruang. Tujuan penelitian pengembangan ini adalah untuk menghasilkan media pembelajaran yang valid, praktis dan efektif. Penelitian pengembangan ini menggunakan model Plomp yang terdiri dari tiga tahap, yaitu: pendahuluan, pembuatan prototipe, dan penilaian. Subjek penelitian ini adalah siswa kelas X SMAN 1 Koto XI Tarusan. Hasil validitas media pembelajaran matematika interaktif berbasis konstruktivisme memiliki kriteria valid pada isi dan konstruk. Media pembelajaran telah memenuhi kriteria praktis karena dapat digunakan dengan baik dalam kegiatan pembelajaran. Media pembelajaran telah memenuhi kriteria efektif karena mampu meningkatkan keaktivan dan hasil belajar siswa sesuai kriteria ketuntasan minimum yang telah ditentukan. Dengan demikian dapat disimpulkan bahwa media pembelajaran matematika interaktif berbasis konstruktivisme yang dikembangkan sudah valid, praktis dan efektif.
\end{abstract}

Kata kunci: Kemampuan Visualisasi, Media Pembelajaran Matematika Berbasis Konstruktivisme, Model Plomp

Copyright (c) 2021 Bambang

$\triangle$ Corresponding author: Lusi Englita

Email Address: lusienglita@ymail.com (Jl.Gaduang No.17, Sumatera Barat, Indonesia)

Received 22 March 2020, Accepted 24 April 2020, Published 30 April 2021

\section{PENDAHULUAN}

Seiring perkembangan zaman, dunia pendidikan juga memerlukan berbagai inovasi. Hal ini penting dilakukan untuk kemajuan kualitas pendidikan. Tuntutan zaman mendorong manusia untuk lebih kreatif dalam mengembangkan atau menerapkan berbagai bidang ilmu, salah satunya pada bidang matematika (Depdiknas, 2008). Matematika adalah salah satu cabang ilmu pengetahuan yang 
mempunyai peranan penting dalam perkembangan ilmu lainnya (Ruseffendi, 1994). Peranan ini tidak hanya dalam cabang MIPA, tetapi mencakup semua bidang ilmu. Salah satu kelompok materi matematika yang harus dikuasai oleh siswa di Sekolah Menengah Atas adalah materi jarak pada bangun ruang. Materi jarak pada bangun ruang ini merupakan sub bagian dari materi dimensi tiga. Materi ini merupakan materi pelajaran kelas X semester II.

Berdasarkan pengamatan yang penulis lakukan pada beberapa SMA di kabupaten Pesisir Selatan, yaitu SMAN 1 Koto XI Tarusan, SMAN 2 Koto XI Tarusan dan SMAN 2 Bayang, dalam proses pembelajaran terlihat masih ada beberapa siswa yang kurang fokus dalam belajar. Pada saat guru menerangkan materi di papan tulis, ada beberapa siswa yang tidak memperhatikan materi yang sedang dipelajari dengan baik, apalagi jika pembelajaran matematika berada pada jam-jam terakhir sekolah. Selain itu, kurang diberdayakannya alat-alat teknologi seperti perangkat komputer disekolah, perangkat teknologi hanya digunakan ketika pelajaran komputer saja, sedangkan untuk pembelajaran lainnya kurang dimanfaatkan oleh pihak sekolah. Ketersediaan media pembelajaran matematikapun tidak banyak ditemui.

Dalam proses pembelajaran guru belum menggunakan media pembelajaran interaktif yang dapat digunakan guru untuk membantu dalam menyampaikan ilustrasi materi pelajaran. Ilustrasi yang disajikan pada media berguna untuk membantu dan membimbing siswa sehingga siswa dapat membangun, menyimpulkan dan memahami isi materi pelajaran dengan baik. Dalam hal mengilustrasikan materi jarak pada bangun ruang, guru menggambarkannya di papan tulis. Jika ilustrasi materi digambarkan di papan tulis maka ilustrasi materi kurang terlihat oleh siswa. Bagian yang merupakan jarak yang diinginkan tidak nampak secara langsung oleh siswa sehingga siswa sulit untuk memvisualisasikan ilustrasi materi dipelajari tersebut, sedangkan pemvisualisasian ini dapat membantu siswa dalam memahami materi pelajaran. Oleh karena itu, perlu dilakukan suatu upaya untuk mengatasi permasalahan tersebut, yaitu dengan menyediakan suatu media pembelajaran yang dapat digunakan pada kegiatan pembelajaran di sekolah.

Salah satu media pembelajaran yang dapat digunakan adalah media pembelajaran matematika interaktif. Dengan adanya media pembelajaran matematika interaktif dapat membantu siswa dalam memvisualisasi materi, karena bagian yang merupakan jarak pada bangun ruang dapat terlihat secara langsung dan jelas (Asyhar, 2011). Salah satu contoh media pembelajaran matematika interaktif adalah media pembelajaran matematika interaktif berbasis kosntruktivisme.

Dengan adanya media pembelajaran matematika interaktif yang berbasis konstruktivisme ini, dalam proses belajar siswa tidak hanya menerima pengetahuan atau materi begitu saja, tetapi siswa dibimbing dan diarahkan sehingga siswa bisa membangun pengetahuan tersebut sendiri yang kemudian siswa juga bisa menemukan dan menyimpulkan materi pelajaran dengan sendirinya (Muslich, 2008). Hal ini sesuai dengan pandangan konstruktivis yaitu dalam kegiatan pembelajaran siswa membangun sendiri pengetahuan mereka melalui keterlibatan aktif dalam pembelajaran. Setiap pengetahuan atau kemampuan dapat diperoleh dan dikuasai oleh seseorang apabila orang itu secara 
aktif mengkonstruksi pengetahuan atau kemampuan tersebut didalam pikirannya. Jika pengetahuan itu bisa dikonstruksi dan ditemukan sendiri oleh siswa, dimungkinkan pengetahuan tersebut akan bertahan lama dan pemahaman siswa terhadap materi pelajaran menjadi lebih baik. Dengan demikian maka pembelajaran akan terasa lebih bermakna(Suherman, 2003) .

Berdasarkan uraian masalah yang telah dikemukakan, maka dilakukan penelitian untuk menghasilkan media pembelajaran matematika interaktif berbasis konstruktivisme untuk siswa sma kelas x pada materi jarak pada bangun ruang yang memenuhi kriteria validitas, praktikalitas dan efektifitas.

\section{METODE}

Jenis penelitian ini adalah penelitian pengembangan dengan menggunakan model plomp yang terdidri dari fase pendahuluan (preliminary research), fase pengembangan atau pembuatan prototipe (prototyping stage), dan fase penilaian (assessment stage) (Plomp, 2013). Pada fase preliminary research terdiri dari analisis kebutuhan, analisis kurikulum, analisis siswa dan analisis konsep. Pada fase pengembangan atau pembuatan prototype (development or prototyping phase) dirancang media pembelajaran berbasis konstruktivisme. Pada prototyping stage, pembuatan prototipe ini dilakukan evaluasi formatif. Fase pengembangan atau pembuatan prototipe (prototyping stage) terdiri atas prototipe 1, yaitu evaluasi diri sendiri (self-evaluation) dan expert review; prototipe 2, yaitu evaluasi satu-satu; prototipe 3, yaitu evaluasi kelompok kecil, dan prototipe 4 yang merupakan hasil dari evaluasi formatif. media pembelajaran berbasis konstruktivisme yang telah dirancang dievaluasi sendiri (self-evaluation) dan divalidasi oleh para ahli (expert review). Validasi perangkat dilakukan oleh dua orang dosen matematika, dua orang dosen teknologi pendidikan dan satu orang dosen bahasa Indonesia. Setelah dihasilkan media pembelajaran berbasis konstruktivisme yang valid, dilakukan evaluasi orang per orang (one-to-one), evaluasi kelompok kecil (small group) dan uji coba lapangan (field test) untuk melihat kepraktisan. Pada fase penilaian (assessment stage), dilakukan uji lapangan pada kelas X SMAN 1 Koto XI Tarusan untuk melihat praktikalitas dan efektivitas. Data penelitian dikumpulkan melalui lembar validasi, lembar pedoman wawancara guru dan siswa, lembar angket respon guru dan siswa, lembar aktivitas siswa dan hasil tes siswa setelah menggunakan media pembelajaran.

\section{HASIL DAN DISKUSI}

\section{Fase Pendahuluan (Preliminary Research)}

Kegiatan pada fase pendahuluan dimulai dengan analisis kebutuhan, analisis kurikulum, analisis siswa dan analisis konsep. Uraian hasil fase pendahuluan adalah sebagai berikut:

\section{Analisis Kebutuhan}

Pada tahap analisis kebutuhan dilakukan pengumpulan informasi mengenai permasalahan yang terdapat dalam pembelajaran matematika. Pengumpulan informasi dilakukan dengan mewawancarai 
beberapa orang peserta didik dan guru. Kegiatan yang dilakukan juga mengobservasi media pembelajaran yang ada di lapangan dan kegiatan pembelajaran.

Hasil yang diperoleh dari analisis kebutuhan adalah pembelajaran disekolah belum berjalan optimal. Guru sudah menerangkan materi dengan baik, hanya saja guru lebih cenderung mendominasi pembelajaran. Labor komputer disekolah kurang diberdayakan. Berdasarkan wawancara dengan guru disampaikan bahwa minat siswa dalam belajar matematika memang kurang. Keterbatasan penggunaan media dalam proses pembelajaran disebabkan keterbatasan guru dalam membuat alat peraga dan media pembelajaran.

Disekolah media pembelajaran yang tersedia pun juga tidak banyak, Media pembelajaran dengan menggunakan tekonologi belum ada disekolah. Berdasarkan wawancara dengan siswa, siswa mengalami kesulitan memahami materi pelajaran. Siswa juga kurang menyukai pelajaran matematika. Ketika ditanya tanggapan siswa terhadap media dan alat peraga matematika disekolah, beberapa diantara mereka menanggapinya dengan positif hanya saja mereka berharap akan adalagi suatu media pembelajaran yang berbeda sehingga menjadi lebih menarik untuk dilihat. Media yang mereka harapkan bisa lebih interaktif, tersaji dengan bahasa yang mudah dimengerti, berisikan materi yang singkat dan berhubungan dengan persoalan matematika pada kehidupan sehari-hari.

\section{Analisis Kurikulum}

Analisis kurikulum bertujuan untuk mengetahui apakah materi jarak pada bagun ruang (SK dan KD) yang ada pada kurikulum sesuai dengan kompetensi yang diharapkan, apakah materi tersebut sudah memadai untuk mencapai tujuan pembelajaran dan apakah materi tersebut sudah terurut dengan baik. Standar kompetensi (SK) yang dipedomani dalam pengembangan media pembelajaran ini adalah SK 6 yang berbunyi menentukan kedudukan, jarak, dan besar sudut yang melibatkan titik, garis, dan bidang dalam ruang dimensi tiga. Standar kompetensi ini terbagi menjadi tiga kompetensi dasar (KD). Media interaktif yang dikembangkan pada penelitian ini mencakup pada KD 6.2. yaitu menentukan jarak yang melibatkan titik, garis, dan bidang dalam ruang dimensi tiga.

Untuk memudahkan guru dalam mendeteksi kemampuan siswa pada KD 6.2 maka peneliti merinci tujuh indikator pencapaian kompetensi yaitu siswa mampu menentukan jarak titik ke titik, jarak titik ke garis, jarak titik ke bidang, jarak garis dengan bidang, jarak bidang dengan bidang, jarak dua garis sejajar dan jarak dua garis yang bersilangan pada bangun ruang.

Untuk mencapai kompetensi pada KD yang telah ditetapkan, konsep yang sudah ditentukan disajikan dalam media pembelajaran interaktif berbasis konstruktivis. Isi media disajikan berbasis konstruktivis, yang mana materi pelajaran tidak langsung disajikan begitu saja. Pada awal penyajian materi siswa diberikan animasi dan ilustrasi yang membantu siswa untuk membangun dan membimbing siswa dalam membangun dan memahami materi. Setelah itu siswa diperlihatkan contoh dari konsep yang dipelajari kemudian siswa diminta untuk menuliskan contoh yang lain dari konsep yang dipelajari. Selanjutnya siswa diminta untuk menarik kesimpulan dari materi yang dipelajari tersebut. 


\section{Analisis Siswa}

Kegiatan analisis siswa bertujuan untuk mengetahui kualitas perseorangan yang dapat dijadikan petunjuk dalam perancangan media pembelajaran. Fokus kegiatan analisis ini adalah pada kondisi, karakteristik, kecenderungan gaya belajar, kemampuan dasar siswa dan bagaimana bekal siswa dalam menggunakan media pembelajaran.

Berdasarkan pengamatan yang peneliti lakukan menunjukkan bahwa yang pertama, bahwa siswa mempunyai rasa ingin tahu. Kedua, selama proses pembelajaran berlangsung sebagian siswa tidak fokus memperhatikan penjelasan guru dan berbicara dengan teman sebangkunya. Ketiga pada saat jam isritahat selain meluangkan waktu untuk makan, siswa juga memanfaatkan waktunya untuk melihat HP, notebook dan laptop mereka. Yang dilihat siswapun beragam, ada yang sedang bermain game, ada yang sedang membuka sosial media mereka, ada yang sedang mencari-cari informasi lain di internet dan ada juga yang sedang membaca buku-buku elektronik.

Berdasarkan wawancara yang dilakukan dengan siswa, pada umumnya siswa sudah mahir dalam mengoperasikan komputer atau sejenisnya. Secara keseluruhan siswa senang bermain game yang ada dikomputer. Hal itu disebabkan adanya bentuk interaksi yang terjadi antara pemain dan game itu sendiri. Siswa cenderung menyukai hal-hal yang disajikan dengan komputer. Tayangan materi yang penuh warna dan bergerak membuat mereka menjadi termotivasi belajar walaupun yang dipelajari adalah matematika

\section{Analisis Konsep}

Analisis konsep bertujuan untuk menentukan isi dan materi pelajaran yang dibutuhkan dalam pengembangan media pembelajaran. Dengan cara mengidentifikasi konsep-konsep utama yang diajarkan, merinci dan menyusunnya secara sistematis.

Pada media pembelajaran, penyajian konsep diawali dengan memberikan ilustrasi dan animasi yang bertujuan mengarahkan siswa dalam memahami konsep materi pelajaran. Contoh dari konsep disajikan sebelum siswa menyimpulkan sendiri konsep tersebut. Hal ini bertujuan untuk memudahkan siswa menyimpulkan konsep materi pelajaran. setelah memperhatikan animasi, ilustrasi materi dan contoh jarak pada bangun ruang tersebut maka siswa diminta untuk menyimpulkan sendiri defenisi jarak pada bangun ruang sesuai pendapatnya masing-masing.

\section{Fase Pembuatan Prototype}

Berdasarkan hasil analisis pada tahap preliminary research maka dirancang dan dibuatlah media pembelajaran matematika interaktif.

1. Perancangan Media Pembelajaran

Hasil perancangan media pada tahap awal disebut dengan prototipe 1. Selanjutnya media pembelajaran divalidasi untuk memperoleh media yang valid. Dua langkah yang dilakukan dalam validasi media pembelajaran, yaitu validitas konstruk dengan melakukan self evaluation dan validitas isi dengan mendiskusikan media pembelajaran kepada 5 orang ahli. Berikut diuraikan hasil validasi prototype 1 media pembelajaran yang telah dirancang. 
a. Self-Evaluation Media Pembelajaran

Kegiatan pertama yang dilakukan setelah merancang media pembelajaran adalah diperiksa sendiri oleh peneliti. Sebelum mengkonsultasikan dan mendiskusikan kepada para ahli, dilakukan evaluasi diri sendiri (self-evaluation) terlebih dahulu terhadap media pembelajaran yang telah dirancang.

Kesalahan yang terjadi pada kegiatan self-evaluation adalah adanya tombol navigasi yang tidak berfungsi pada bagian contoh soal dan animasi yang tidak berjalan sempurna pada materi jarak dua garis yang sejajar. Setelah dilakukan evaluasi diri sendiri terhadap media pembelajaran matematika interaktif berbasis konstruktivisme yang telah dirancang selanjutnya dilakukan perbaikan. Hasil perbaikan ini kemudian dikonsultasikan dan didiskusikan dengan pakar atau ahli.

b. Hasil Validasi Media Pembelajaran Oleh Para Ahli

Kegiatan validasi dilakukan oleh lima orang validator yang terdiri dari dua orang dosen matematika, satu orang dosen bahasa Indonesia dan dua orang dosen teknologi pendidikan. Dari kegiatan validasi didapat saran-saran untuk perbaikan media pembelajaran. Validator menyarankan untuk memberikan lambing pada bagian cover, memberikan kata maju atau mundur pada tombol navigasi untuk halaman selanjutnya atau sebelumnya, memberikan tanda tunjuk untuk setiap tombol navigasi animasi, mendesain menu latihan agar lebih interaktif (dilakukan dengan tampilan jawaban yang dapat langsung merespon kebenaran jawaban siswa) dan menghilangkan background yang bergerak pada layar media dengan tujuan agar siswa bisa lebih fokus melihat pergerakan animasi media pembelajaran. Dari saran-saran validator tersebut maka dilakukanlah perbaikan media pembelajaran, hasil perbaiakn media pembelajaran itu disebut prototype 2 .

Rata-rata hasil penilaian validasi untuk aspek materi dan isi memiliki nilai 3,33 dengan kategori sangat valid, 3,5 dengan kategori sangat valid untuk aspek bahasa dan 3,18 dengan kategori sangat valid untuk aspek rekayasa perangkat lunak dan komunikasi visual. Gabungan dari ketiga aspek tersebut memiliki nilai validasi 3,34 dengan kategori sangat valid. Dengan demikian media pembelajaran dapat disimpulkan valid dan bisa digunakan pada tahap selanjutnya (uji coba lapangan).

\section{Uji Coba Lapangan}

Uji coba lapangan pada fase prototyping terbagi atas dua yaitu tahap one-to-one evaluation dan tahap small group evaluation. Berikut hasil dari tahap tersebut:

\section{a. One-to-one Evaluation}

Pada tahap one-to-one evaluation produk diujicobakan pada tiga orang siswa. Tujuan one-to-one evaluation adalah untuk mengidentifikasi kemungkinan kesalahan (error) seperti tata bahasa yang kurang dimengerti, ejaan yang salah, tanda baca, petunjuk yang kurang jelas, kesesuaian contoh, sistematika materi, kemudahan penggunaan, kemenarikan, dan kepuasaan.

Berdasarkan wawancara dengan siswa, dapat dismpulkan bahwa dari segi sistematika materi yang disajikan sudah tersusun dengan baik dan rapi. Langkah-langkah penyajian materi juga tersusun secara teratur. Dari segi keterbacaan ditemukan beberapa kesalahan dalam pengetikan huruf maupun 
pengulangan kata yang tidak diperlukan. Seperti kata "kubus ADCD" (seharusnya ABCD), kata "buatlah contoh jarak titik ke titik yang lain" (seharusnya jarak titik ke titik yang lainpada buku latihanmu" dan kata "jarak garis A dengan $\mathrm{HG"} \mathrm{(seharusnya} \mathrm{jarak} \mathrm{garis} \mathrm{AB}$ dengan $\mathrm{HG}$ ).

Hasil analisis angket kepraktisannya memiliki rata-rata tingkat persentase kepraktisan 74,31\% (kategori praktis) pada pertemuan pertama, 76,39\% (kategori praktis) pada pertemuan kedua dan $66,67 \%$ (kategori praktis) pada pertemuan ketiga. Beberapa kesalahan yang ditemukan pada tahap one-to-one evaluation dilakukanlah perbaikan, hasil perbaikan media pembelajaran tersebut dinamakan dengan prototipe 3 yang dapat digunakan untuk uji coba lapangan tahap selanjutnya.

\section{b. Small Group Evaluation}

Pada tahap small group evaluation produk diujicobakan pada enam orang siswa. Tujuan dari tahap small group evaluation ini adalah untuk mengidentifikasi kekurangan dari prototipe pada tahap sebelumnya.

Hasil yang ditemukan pada tahap small group evaluation adalah siswa masih ragu menggunakan tombol-tombol navigasi yang ada pada media pembelajaran. Hal ini disebabkan oleh banyaknya siswa yang tidak membaca petunjuk penggunaan media pembelajaran dengan baik. untuk mengatasi permasalahan ini maka peneliti membuat kartu yang berisi petunjuk penggunaan dan urutan materi yang ada pada media. Sehingga ketika siswa lupa dengan fungsi tombo, navigasi mereka dengan mudah melihat kartu tanpa harus menuju menu petunjuk pada media dan kemudian kembali lagi pada materi yang sedang mereka pelajari.

Permasalahan selanjutnya yang ditemukan pada tahap ini adalah beberapa siswa kurang mendengarkan informasi lisan tentang syarat yang harus dipenuhi dalam menentukan jarak pada bangun ruang khususnya pada materi jarak antara dua garis bersilangan. Oleh karena itu peneliti juga melakukan perbaikan dengan menuliskan syarat tersebut pada slide materi. Hasil perbaikan yang peneliti lakukan pada tahap small group ini disebut dengan prototipe 4.

Berdasarkan angket kepraktisan yang diisi siswa diperoleh nilai rata-rata tingkat kepraktisan $83,85 \%$ (sangat praktis) untuk aspek kemudahan penggunaan,78,39\% (praktis) untuk aspek waktu yang diperlukan, 78,82 (sangat praktis) untuk aspek daya tarik perangkat, 84,38 (sangat praktis) untuk aspek mudah diinterpestasikan, 81,94 (sangat praktis) untuk aspek memiliki ekivalensi yang sama sedangkan rata-rata untuk kelima aspek tersebut adalah $81,25 \%$ (sangat praktis).

\section{Fase Penilaian (Assessment Stage)}

Fase penilaian merupakan fase terakhir dari kegiatan pengembangan. Fase penilaian bertujuan untuk mengetahui sejauh mana kepraktisan dan keefektifan perangkat pembelajaran matematika yang dikembangkan dalam pelaksanaan pembelajaran. Pada penelitian jumlah subjek yang menjadi uji coba adalah sebanyak satu kelas.

1. Kepraktisan Media Pembelajaran

Kepraktisan media pembelajaran diketahui setelah peneliti melakukan uji coba. Subjek dari ujicoba kepraktisan ini adalah guru dan siswa. Peneliti menggunakan angket untuk melihat respon 
guru dan siswa terhadap kepraktisan media pembelajaran matematika interaktif.

a. Respon Guru

Hasil analisis angket kepraktisan media pembelajaran matematika interaktif berbasis konstruktivis yang diisi guru menunjukkan bahwa media tersebut berkategori sangat praktis dengan skor rata-rata tingkat kepraktisan 87,50. Kategori sangat praktis didapat dari lima aspek yang menjadi penilaian terhadap media pembelajaran yang terdiri dari 1)kemudahan pemggunaan, 2) waktu yang diperlukan, 3) daya tarik perangkat, 4) mudah diinterpestasikan dan 5) memiliki ekivalensi yang sama.

b. Respon Siswa

Tingkat kepraktisan yang diberikan siswa setelah pelaksanaan penelitian mencapai skor rata-rata 81,14 dengan kriteria sangat praktis. Pada angket siswa menilai media pembelajaran interaktif dari lima aspek yaitu, 1) kemudahan pemggunaan, 2) waktu yang diperlukan, 3) daya tarik perangkat, 4) mudah diinterpestasikan dan 5) memiliki ekivalensi yang sama. Tingkat kepraktisan yang diperoleh dari kelima aspek tersebut meliputi 81,83\% untuk aspek kemudahan penggunaan, 79,27\% untuk aspek waktu yang diperlukan, $82,52 \%$ untuk aspek daya tarik perangkat, 79,88\% untuk aspek mudah diinterpestasikan dan $81,30 \%$ untuk aspek memiliki ekivalensi yang sama.

Dari komentar tertulis yang diberikan siswa pada umumnya mereka senang belajar dengan media pembelajaran interaktif. Hal ini disebabkan daya tarik pada media, mudah digunakan, penyajian evaluasi yang langsung mengoreksi kebenaran jawaban siswa.

Dari pelaksanaan pembelajaran guru tidak lagi mendominasi kegiatan pembelajaran, karena siswa bisa dengan mudah mempelajari materi yang sudah disajikan dalam media pembelajaran interaktif. Siswa juga dengan bebas melihat animasi-animasi materi secara berulang jika mereka belum memahami materi yang dipelajari, tanpa menganggu temannya yang lain. Kegiatan pembelajaran dengan menggunakan media pembelajarapun menjadi lebih aktif karena siswa bisa melihat langsung animasi-animasi materi sebagai sumber pengetahuan visual mereka.

\section{Efektivitas Media Pembelajaran}

Efektivitas media pembelajaran dapat dinilai dari dua aspek yaitu aspek aktivitas siswa selama kegiatan pembelajaran berlangsung dan aspek hasil tes akhir siswa setelah materi pelajaran dengan menggunakan media selesai dilaksanakan.

\section{a. Aktivitas Belajar Siswa}

Hasil pengamatan aktivitas siswa selama proses pembelajaran berlangsung dengan menggunakan media pembelajaran matematika interaktif berbasisi konstruktivis diketahui sangat baik, hal ini terlihat dari rata-rata persentase aktivitas siswa dengan nilai 84,10\%. Aktivitas yang menjadi penilaian ada enam yaitu kegiatan siswa dalam memperhatikan gambar, demonstrasi dan ilustrasi, membaca petunjuk dan keterangan media, bertanya kepada guru, mengemukakan pendapat, mengerjakan soal latihan dan belajar dengan serius dan gembira.

Dari keenam aktivitas tersebut, aktivitas yang paling menonjol dilakukan siswa adalah 
memperhatikan demonstrasi dan ilustrasi pada media dan mengerjakan latihan. Hal ini disebabkan oleh kesukaan siswa terhadap animasi-animasi yang disajikan. Selan itu, tampilan menu latihan dan evaluasi yang disajikan juga membuat siswa tertarik untuk menjawab soal-soal yang ada pada media, karena siswa bisa langsung mengoreksi kebenaran jaban mereka dan mengulangi kegiatan tersebut sampai mereka mendapatkan nilai sesui dengan keinginan masing-masing.

Aktivitas bertanya kepada guru lebih rendah dibandingkan aktivitas yang lain. Dari hasil pengamatan siswa tidak terlalu banyak bertanya kepada guru, karena siswa asyik mempelajari media pembelajaran interaktif. Kegiatan bertanya dominan terlihat pada pertemua pertama, karena pada awal pertemuan siswa masih sedikit bingung mengguanaknmedia tersebut. Namun, dalam hal ini guru menghampiri siswa yang bingung dan menjelaskan penggunaan media dan tombol-tombol navigasinya. Dari hasil pengamatanpun siswa juga terlihat senang dengan adanya media pembelajaran matematika interaktif berbasisi konstruktivisme ini. Secara umum, kegiatan aktivitas siswa dengan menggunakan media pembelajaran matematika interaktif bisa dikatakan baik, karena rata-rata semua siswa ikut terlibat aktif dalam proses pembelajaran.

b. Hasil Tes

Tes hasil belajar digunakan untuk mengetahui efektivitas media pembelajaran interaktif. Tujuan dari penilaian hasil belajar adalah mengukur tingkat keberhasilan siswa dalam proses pembelajaran. Dalam penelitian ini tes dilaksanakan diakhir materi pelajaran. Soal tes terdiri dari sepuluh soal dan berbentuk essay. Soal tes diikuti oleh 38 orang siswa. Dari hasil penilaian terhadap uji tes akhir terdapat 31 orang siswa tuntas dan 7 orang sisa tidak tuntas (nilai yang duperoleh dibawah KKM) dengan rata-rata siswa tuntas adalah $81,58 \%$. Persentase ketuntasan yang diperoleh sudah berada diatas ketuntasan klasikal yang ditetapkan yaitu $65 \%$. Hal ini berarti media pembelajaran matematika telah mampu membawa siswa mencapai pemahaman yang diinginkan oleh standar kompetensi dan kompetensi dasar.

\section{KESIMPULAN}

Berdasarkan hasil analisis data yang telah dilakukan dapat disimpulkan bahwa media pembelajaran matematika interaktif berbasis konstruktivisme pada materi jarak pada bangun ruang yang dirancang telah valid, praktis, dan efektif digunakan untuk meningkatkan kemampuan visualisasi siswa dan keaktifan siswa dalam pembelajaran. Berdasarkan simpulan di atas, maka media pembelajaran matematika interaktif berbasis konstruktivisme pada materi jarak pada bangun ruang dapat dijadikan sebagai pedoman bagi guru dalam melaksanakan pembelajaran untuk meningkatkan kemampuan visualisasi siswa dan memudahkan siswa dalam memahami materi jarak pada bangun ruang.

\section{REFERENSI}

Muslich, Masnur. 2008. KTSP Pembelajaran Berbasis Kompetensi dan Kontekstual. Jakarta : Bumi 
Aksara

Plomp, T dan N. Nieveen. 2013. Educational Design Research. Enshede: Netherlands Institute For Curriculum Development (SLO)

Asyhar, R. 2011. Kreatif Mengembangkan Media Pembelajaran. Jakarta: Gaung Persada Pres

Depdiknas. 2008. Panduan Pengembangan Bahan Ajar. Jakarta: Direktorat Jendral Manajemen Pendidikan Dasar dan Menengah

Ruseffendi,E.T. 1994. Matematika dan Komputer Basic. Bandung: Tarsito

Suherman, Erman. 2003. Strategi Pembelajaran Matematika Kontemporer. Bandung: Universitas Pendidikan Indonesia 